\title{
Coordination and agility: How is the correlation in improving soccer dribbling skills?
}

\author{
Nurkadri $^{*}$, Basyaruddin Daulay, Fauzan Azmi \\ Universitas Negeri Medan, Indonesia
}

Received: 31 January 2021; Accepted 16 May 2021; Published 20 July 2021 Ed 2021; 6(2): 147-161

\begin{abstract}
Investigation that was raised in this study was to improve dribbling skills. One form of training that must be done is coordination training and agility training for the players of the Tunas Muda Medan Football School (SSB TMM). Furthermore, it is expected that discoveries can be made that can improve dribbling skills with other training components for soccer players in soccer schools. This study aims to improve the skills of dribbling SSB TMM players in the city of Medan, North Sumatra Province by using coordination training and agility training. The experimental population was all SSB TMM players with a sample of 22 people. The research method used is descriptive with a correlational process, the analysis system is used to test the hypothesis which is the normality test, linearity test, and correlation test. From the end of the first hypothesis correlation test, a significance value of $0.046<0.050$ is obtained, so there is a significant relationship between coordination on the results of the ability of dribbling ball. The achievement of the second hypothesis test has a significance value of $0.037<0.05$, so there is a significant relationship between agility and the results of the ability to dribble a ball. Based on the multiple regression test, it is known that the significance is $0.037<0.05$, then $\mathrm{H}_{0}$ is not accepted and $\mathrm{H}_{\mathrm{a}}$ is accepted. Thus, the two components of coordination and agility simultaneously have a significant relationship with the ability to dribble a ball.
\end{abstract}

Keywords: Ankle harmonization; dexterity; dribbling

https://doi.org/10.25299/sportarea.2021.vol6(2).6355

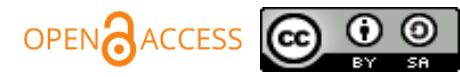

Copyright @ 2021 Nurkadri, Basyaruddin Daulay, Fauzan Azmi

Corresponding author: Nurkadri, Department of Sport Coaching, Faculty of Sport Science, Universitas Negeri Medan, Medan, Indonesia

Email: nurkadri@unimed.ac.id

How to Cite: Nurkadri., Daulay, B., \& Azmi, F. (2021). Coordination and agility: How is the correlation in improving soccer dribbling skills?. Journal Sport Area, 6(2), 147-161. https://doi.org/10.25299/sportarea.2021.vol6(2).6355

\section{INTRODUCTION}

The existence of sport is now very necessary in the sustainability of society, where sport is an important integral of comprehensive development in fostering, as well as development that leads to increased health, intellectual and mental as a form of personal discipline and sportsmanship as achievement in all sports (Jamalong, 2014; Prakoso \& Sugiyanto, 2017; Hardiyono et al., 2019). So maintaining health, intellectual and clean soul, forming a disciplined personality and high sportsmanship are one of the activities to achieve achievement in national development, it is very necessary to improve health intellectually and mentally to form a sportsmanship and disciplined personality. The goal of achieving this achievement in all sports, including football, which is a popular sport.

Football is one of the most popular sports in the world and is played by men and women, children and adults of all skill levels. The appearance of a football player depends on several factors such as technique/biomechanics, tactical mental, and physiological (Stolen, Chamari, Castagna, \& Wisloff, 2005). 
Football is a sport that is always intense in physical contact involving a relatively high risk and rate of injury to professional players, amateurs, and young players during training and matches. Players play faster and depending on the importance of playing more aggressively than football in the past, players need increased physical fitness and more intensive training especially at the professional level (Hawkins, \& Fuller, 1999; Woods et al., 2001; Andersen et al., 2004; Junge et al., 2004; Le Gall et al., 2006; Deehan et al., 2007; Kofotolis et al., 2007; Pfirrmann et al., 2016).

The game of football is a sport that is in great demand by the public from the upper caste to the lowest caste so that it is favored by the community, in achieving optimal performance it is necessary for the coach or coach to refer to a scientific basis. The use of science and technology is very helpful in improving football achievement, so what must be done is a study of the factors that can support maximum performance (Palmizal et al., 2019). Furthermore, football as one of several sports that are loved by the community, it is expected that the wishes of the law on the sports system in Indonesia can be realized. Therefore, it is common place that football is currently very much considered by the government, so for achievement it is necessary to start with learning at school and training in schools through football clubs. The soccer game needed is perfect technique, if you don't master soccer techniques such as kicking goal, passing, dribbling, heading, stopping control perfectly, then the goal of the game, which is to win, will be difficult to achieve (Gazali, 2016). Furthermore, how to play soccer is a form of someone's effort to play soccer or a movement that is very necessary in order to be able to play the ball in a soccer game (Candra, 2016).

From the opinion of Gazali and Candra, the basic techniques of soccer that need to be mastered by players in general are: passing, kicking the goal, dribbling, heading, and stopping control. So it's still from Gazali and Candra who are the elements or stages of dribbling the ball the most thing to remember is the ankle coordination factor because when players do dribbling, players have to look at the conditions and situations when dribbling because of the efforts made by someone in flowing and delaying the ball which is related to the coordination possessed by a player in dribbling the ball. Besides that other supporting factors are agility factors, agility itself is considered an integrated factor to a player's ability to dribbling because agility when someone does dribbling the player must be required to do swerving or twisting. Avoid through the agility possessed by a player, therefore from the explanation above that when a player dribbling the ball the ankle coordination factor and agility are very influential when someone makes a dribbling movement. This is confirmed by the results of research showing that there is a relationship between ankle coordination and the dribbling ability of SSB Excellent soccer players in Batusangkar City, and there is also a link between agility and dribbling abilities of SSB Excellent players in Batusangkar City and there is a close relationship between ankle coordination and joint agility and also the dribbling ability of SSB Excellent Batusangkar football player (Ilmi \& Kiram, 2019).

To perform any motor movement optimally, the subject must improve what is meant by coordination of skills which are divided into basic and special, the connection with this is a solid basis consisting of good motor development and adequate nervous system development allowing information to be processed. Furthermore, we know that this coordination is an external manifestation of nervous system function that is influenced by the environment, so the set of skills used to learn, control, and regulate a movement, subsides is the basis for learning and developing technical skills and is in close interaction with conditional skills (Altavilla et al., 2015; Ceruso et al., 2019; D'elia, 2019; D'Isanto et al., 2019). Coordination is one of the important elements in mastering sports skills, the coordination stages of an arbitrator from mastering a sport skill whose mastery is included in technical skills (Dupri, 2016). From Dupri's opinion, coordination is defined as the work of a procedure or something different, based on physiological coordination is the work of the central nervous system with muscles to get maximum power. In other words, coordination is often seen from the meaning or naming for the work support abilities of different motion processes, for example in learning, learning movement skills, ability to control motion and the ability to switch and adjust motion.

So from several literatures such as Bob Davis et al., stated that the ability to show basic movements is smooth and precise, always involves the use of feelings and is associated with a series of muscle contractions in influencing the mixture of body parts and body position (Supriadi, 2015). Mackinnon and Winter further argue that coordination makes it possible to understand how multiple joints work 
collaboratively to achieve a goal of motion, providing additional information on the kinematics of each individual joint. It is recommended that the hips and subtalars work synergistically to control foot movement during walking (Yen et al., 2017). N.A. confirmed Bernstein that refers to the organization in many joints or segments of all movements is what is meant by coordination (Yen et al., 2017).

Agility starts from being agile in other words agile, is one of the components of the physical fitness of the part that is developed. Agility is one thing where the ability to change the direction and location of body movements quickly and precisely in a short time where the body is in a state of motion without losing balance and a sense of awareness in the body (Perdima, 2017). Furthermore, the agility of all body movements by changing speed or direction in response to one stimulus (Spiteri et al., 2013; Nimphius, 2018). From these two quotes, agility is a physical component that is always used in sports, which in general is the ability to change direction well and quickly when running or walking in prime condition. And it can be concluded a movement that changes rapidly. This is emphasized by agility most often defined for a change of direction of motion quickly (Altug et al., 1987; Šimonek, Horička, \& Hianik, 2016).

Furthermore, the movement of the whole body as a change in direction or changing the direction of movement in response to a stimulus is the meaning of agility (Gamble, 2013). For example, running back and forth, players should reduce their speed when changing direction. In agility movement activities, the physical component of agility often plays an important role. Agility is an important physical fitness in all activities that require changing the direction of the body position and other parts quickly and precisely (Kharisma \& Mubarok, 2020). Furthermore, agility, one of the important elements of sports performance, especially in games and martial arts, it also includes the speed of change in the direction of movement of a player and coupled with cognitive factors (Young et al., 2002; Zemková \& Hamar, 2009; Horicka et al., 2018). Based on several theories and also the author's observations that the SSB Tunas Muda Medan soccer player ankle coordination when dribbling is not adequate in other words bad, then when carrying the ball is still poor in agility and poor in controlling the ball. So from the author's observations and several existing theoretical studies, the most basic problem in this research is the dribbling ability of the SSB TMT players' balls is still lacking in other words it is still far from what is expected. This is reinforced by the results of interviews conducted by the author to the coach in order to reveal the problems that exist in the field, the coach assumes that there is a relationship between ankle coordination and agility on a player's ability to perform basic ball dribbling techniques. Meanwhile, Sakti's research (2017) showed a relationship between ankle coordination and agility in the dribbling data of soccer games. So, deductively, researchers are interested in revealing the truth of the theories that have been described, as well as the desire of researchers to improve the dribbling of the ball for the SSB TMT players in Medan city through elements of ankle coordination exercises and elements of agility training for the better. Researchers in this study intend to seek the truth of the theory of coordination and agility will affect the ball dribbling ability of players at SSB TMM Medan city, and seek to improve the ball dribbling ability of players at SSB TMM Medan city. Furthermore, the novelty of this research is to find the truth of previous research and the truth in improving the ball dribbling ability of SSB TMM players, one of which must be trained in ankle coordination and continuous agility training.

\section{METHOD}

The research method used in this study is a descriptive research method using correlational techniques. Descriptive research is research that is intended to investigate the circumstances, conditions or other things that have been mentioned, the results of which are presented in the form of a research report (Arikunto, 2013). Regarding correlational or relationship techniques, correlation research or correlational research is research conducted by researchers to determine the level of relationship between two or more variables, without making changes, additions or manipulations to existing data (Arikunto, 2013). Next, correlational research is divided into two, namely parallel correlational research and causal research. Parallel research only aligns two or more variables while causal correlational research is to find out whether there is a relationship between one variable with another variable (Arikunto, 2013). In this study, the causal correlation technique was used because it looked for the relationship between ankle coordination and agility 
on the ability to dribble in soccer. This correlational research intends to determine the relationship between the independent variable and the dependent variable and to see how big the contribution is. The independent variable is coordination (X1) and agility (X2) while the dependent variable is dribbling capacity (Y), coordination and agility of ball dribbling skills.

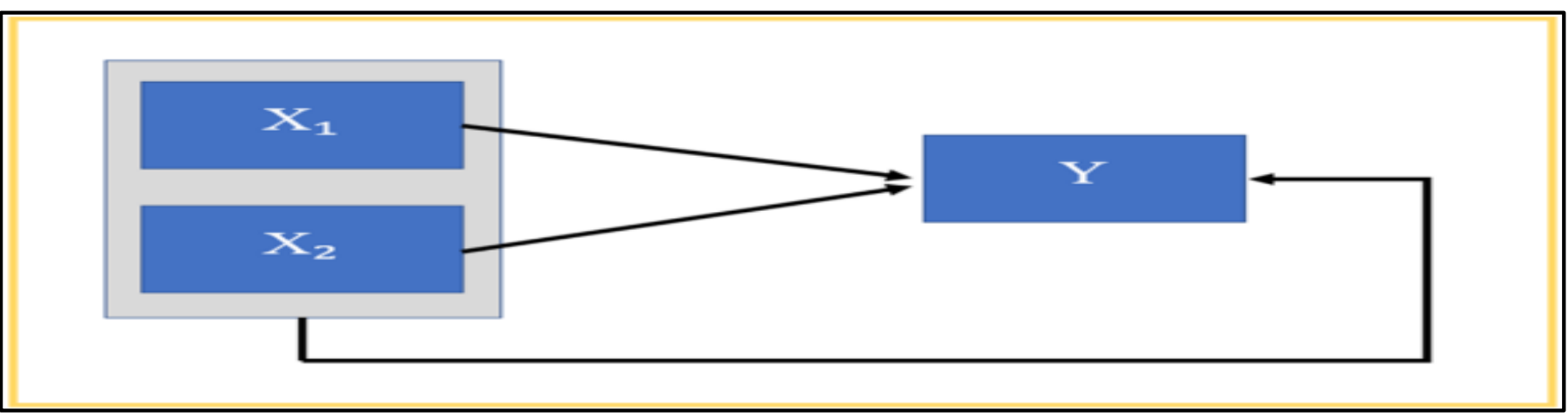

Figure 1. Research Design

(Arikunto, 2013)

The use of data in correlational research uses primary and secondary data. The primary data comes from the research sample, and the subordinate data comes not from the sample but from other sources, both written and oral. Primary source acquisition is obtained by verification results on players which include:

\section{Agility Test}

Shuttle Run 6 x 10 Meters which aims to determine the level of agility, implementation as follows; (1). Tastee stands behind the starting line. (2). If there is a "yes" signal, the testee runs as fast as possible following the direction of the arrow according to the diagram to the finish line. (3). Each testee was given the opportunity to do this test 3 times, and the best time was taken (Udam, 2017).

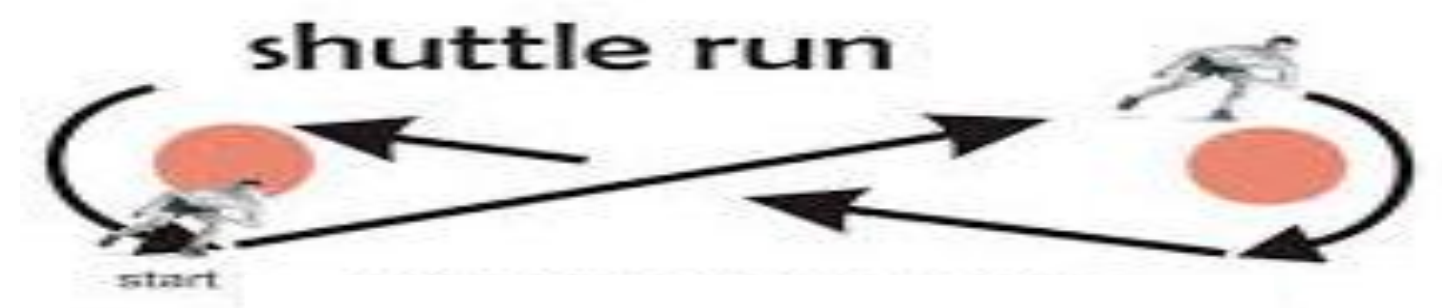

Figure 2. Shuttle Run Test Instruments

Table 1. Shuttle Run Test Norms

\begin{tabular}{cccccc}
\hline Gender & Very Good & Good & Enough & Medium & Less \\
\hline Male & $>15.5 \mathrm{sec}$ & $15.6-16 \mathrm{sec}$ & $16.1-16.6 \mathrm{sec}$ & $16.7-17.1 \mathrm{sec}$ & $<17.2 \mathrm{sec}$ \\
\hline Female & $>16.7 \mathrm{sec}$ & $16.8-17.4 \mathrm{sec}$ & $17.5-18.2 \mathrm{sec}$ & $18.3-18.9 \mathrm{sec}$ & $<19.00 \mathrm{sec}$ \\
\hline
\end{tabular}

(Udam, 2017)

\section{Ankle Coordination Test}

The movement of the ball trajectory under constant conditions represents a very useful test model to see the coordination patterns of soccer players at various levels of expertise in ball dribbling (Egan et al., 2007; Tessitore et al., 2011). Hexagonal Obstacle Test; the goal is to measure ankle coordination, the implementation is as follows; the athlete stands in the middle of the hexagon facing lane a. Maintain this 
position during the test i.e. facing line a at the command Yes the stopwatch is run and the player jumps with both feet across line $b$ and back to center, then goes over line $\mathrm{c}$ then back to center and so on until all (6 lines are skipped) when the athlete jumps line a and return to the middle until it can carry out all the jump lines, then the test is considered to have done a series of tests. Players or testers carry out as many as 3 implementations. After completing 3 sets the stopwatch is stopped and the time is recorded. Assessment of this instrument; The tester performs 3 series of jumps and the time is taken in seconds.

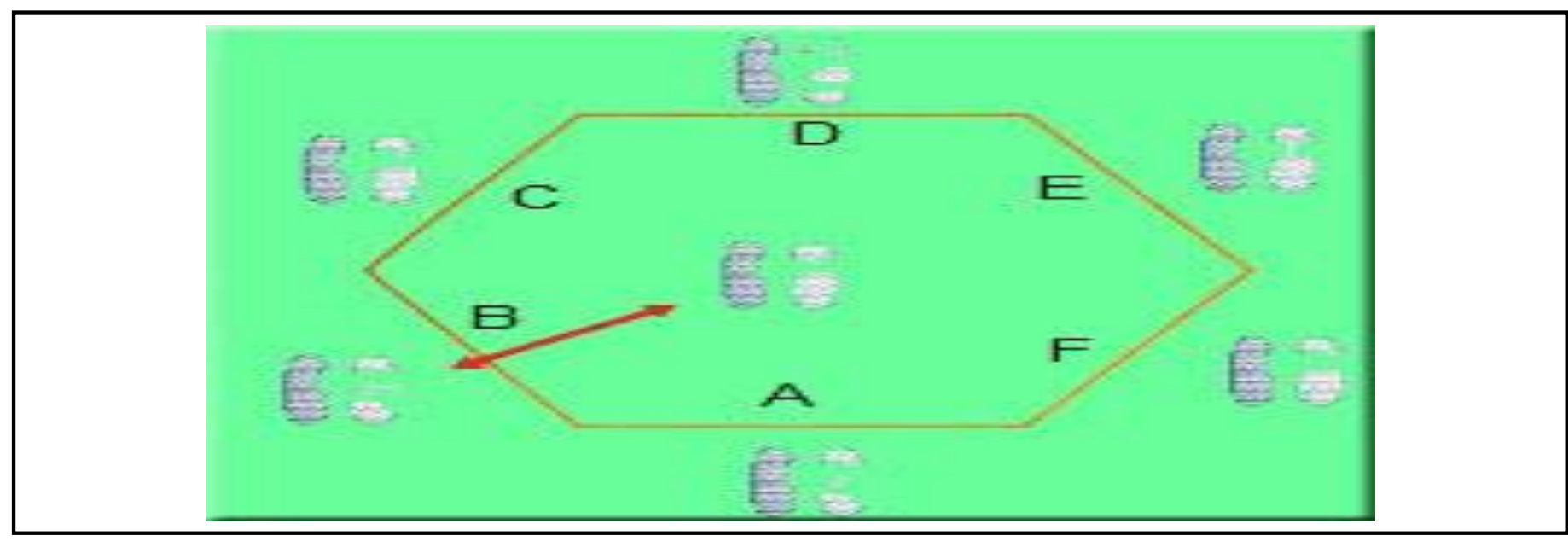

Figure 3. Ankle Coordination Test Instruments

Table 2. Ankle Coordination Test

\begin{tabular}{cccccc}
\hline Gender & Very Good & Good & Enough & Medium & Less \\
\hline Male & $<11.2 \mathrm{sec}$ & $11.2-13.3 \mathrm{sec}$ & $13.4-15.5 \mathrm{sec}$ & $15.6-17.8 \mathrm{sec}$ & $>17.8 \mathrm{sec}$ \\
\hline Female & $<12.2 \mathrm{sec}$ & $12.2-15.2 \mathrm{sec}$ & $15.4-18.5 \mathrm{sec}$ & $18.6-21.8 \mathrm{sec}$ & $>21.8 \mathrm{sec}$ \\
\hline
\end{tabular}

(Susilawati, 2018)

\section{Dribbling Ability Test}

Dribbling ability test; Nurhasan stated that the purpose of measuring the dribbling ability of soccer players is as follows; (1). The player stands in front of the starting line with a ball at his feet ready, (2). Starter and timer give a ready signal (whistle). (3). If the "whistle" is sounded, the athlete immediately dribbles past the pegs that have been arranged and after arriving at the last point returns to the starting blood. The assessment; The tester takes the athlete's time speed in performing ball dribbling skills and for the record: if while dribbling, the ball moves away from the provided peg (no longer reachable) then the tastee is considered a failure (Saputra et al., 2019).

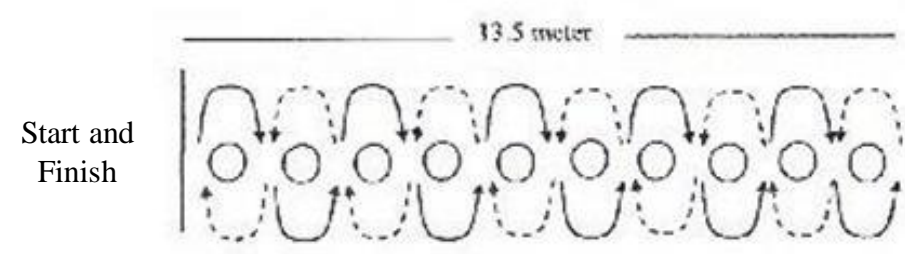

$$
\text { Information : } \begin{aligned}
=\text { Line Start and Finish } \\
=\text { Cones (Distance Betwe Cones } 1,5 \mathrm{~m} \text { ) } \\
=\text { = Direction Dribbling } \\
=\text { Dribbling Back to The Finish }
\end{aligned}
$$

Figure 4. Dribbling Ability Test Instruments 
Meanwhile, secondary data were obtained from documents provided by the management of SSB TMM. The population of this research is SSB TMM with the street address Pasar IV, Helvetia Village, Labuhan Deli District. The population is a generalization area consisting of: objects/subjects that have certain qualities and characteristics determined by the researcher to be studied and then drawn conclusions (Sugiono, 2016). The population in this study was all SSB TMM athletes as many as 149 people. Sampling was carried out using purposive random sampling as many as 22 people in the 12-14 year age group, following the study population in table 3 .

Table 3. Research Population

\begin{tabular}{ccc}
\hline No & Age Group & Number of People \\
\hline $\mathbf{1}$ & U-12 Years Old & 15 \\
$\mathbf{2}$ & U-13 Years Old & 24 \\
$\mathbf{3}$ & U-14 Years Old & 40 \\
$\mathbf{4}$ & U-15 Years Old & 27 \\
$\mathbf{5}$ & U-16 Years Old & 21 \\
$\mathbf{6}$ & U-17 Years Old & 22 \\
\hline
\end{tabular}

The implementation of this research is approximately one year, starting from a needs analysis from October 2019 to data collection and reporting in October 2020. The length of this research is due to the Covid 19 outbreak that is endemic throughout the world. With the outbreak to prevent the spread of the epidemic, the President issued a circular letter regarding Large-Scale Social Restrictions (PSBB). The technique of analyzing data uses conditional correlation, where the conditional correlation uses the correlation formula, namely the sample used is random, where in each variable is normally distributed by having linear regression with data whose test recap is analyzed using statistics, with the formula (Supardi, 2013) as follows:

Get the relationship between $\mathrm{x}$ and $\mathrm{y}$,

$$
r_{x y}=\frac{n \sum X Y-\left(\sum X\right)\left(\sum Y\right)}{\sqrt{\left\{N \sum X^{2}-\left(\sum X\right)^{2}\right\}\left\{N \sum Y^{2}-\left(\sum Y\right)^{2}\right\}}}
$$

(Supardi, 2013)

Find the correlation coefficient of two variables $\mathrm{x} 1$, $\mathrm{x} 1$ together with respect to $\mathrm{y}$,

$$
R_{y .12}=\sqrt{\frac{r_{y 1}^{2} \div r_{y 2}^{2}-2 r_{y 1} \cdot r_{y 2} \cdot r_{12}}{1-r_{12}^{2}}}
$$

(Supardi, 2013)

Double correlation hypothesis test with $\mathrm{F}$ test on degrees of freedom (dk).

Finding the standard deviation of the pre-test recap, $F_{h}=\frac{R^{2} / k}{\left(1-R^{2}\right) / n(-k-l)}$

The premise assessment parameter is accepted $H_{0}$ if $F_{\text {hiutn }}<F_{\text {tabel }}$ and $H_{0}$ if $F_{\text {hiutn }}>F_{\text {tabel }}$ (Supardi, 2013).

\section{RESULTS AND DISCUSSION}

This study was to explore the relationship between ankle coordination and agility on the ball dribbling ability of SSB TMM players in the city of Medan. Description of results of the independent variable and the dependent variable after being discussed is using statistics. Then the results of the analysis of ankle coordination can be seen in table 4 below: 
Table 4. Statistical Results of Ankle Coordination Descriptive Statistics

\begin{tabular}{|c|c|c|c|c|c|c|c|c|c|}
\hline \multicolumn{10}{|c|}{ Descriptive Statistics } \\
\hline & $\mathrm{N}$ & Range & Minimum & Maximum & Sum & \multicolumn{2}{|c|}{ Mean } & $\begin{array}{c}\text { Std. } \\
\text { Deviation }\end{array}$ & Variance \\
\hline & Statistic & Statistic & Statistic & Statistic & Statistic & Statistic & $\begin{array}{l}\text { Std. } \\
\text { Error }\end{array}$ & Statistic & Statistic \\
\hline Ankle Coordination & 22 & 5.00 & 5.00 & 10.00 & 152.00 & 6.9091 & .26243 & 1.23091 & 1.515 \\
\hline Valid N (listwise) & 22 & & & & & & & & \\
\hline
\end{tabular}

Statistical analysis showed that for the ankle coordination variable, the mean value $=6.9091$, range $=$ 5.00 , sum $=152.00$, minimum $=5.00$, maximum $=10.00$, and standard deviation $=1.2309$. Therefore, the description of the results of ankle coordination is shown in table 5 below:

Table 5. Description of the Results of Ankle Coordination

\begin{tabular}{cccc}
\hline Interval & Category & Frequency & Percentage (\%) \\
\hline $\mathrm{X} \geq 21,98$ & Very High & 1 & 4.545 \\
$19,96 \leq \mathrm{X}<21,98$ & High & 7 & 31.818 \\
$17,95 \leq \mathrm{X}<19,96$ & Medium & 9 & 40.909 \\
$15,93 \leq \mathrm{X}<17,95$ & Low & 5 & 22.727 \\
$\mathrm{X} \leq 15,93$ & Very Low & & 0 \\
\hline Amount & & 22 & \\
\hline
\end{tabular}

Likewise with the research of David Armando and Hari Amirullah Rachman where there is a significant difference between high ankle coordination and low ankle coordination on the ball dribbling ability of students aged 12-13 years is stated by the findings of $F=21.780$ and $p=0.000<0.05$ (Armando \& Rahman, 2020). Furthermore, it is supported by the research of Oktarifaldi and Soniawan that there is a significant impact of ankle coordination on the ball dribbling ability of players at the Balai Baru Padang Football Academy of $4.92 \%$ as evidenced by the results obtained by the path coefficient YX2 $=0.222$, the value of sig $=0.016<0.05$ then Ho rejected and Ha accepted using SPSS 17 program calculations (Oktarifaldi et al., 2020). Then there is a relationship between ankle coordination on ball playing skills, it is revealed that players who have good ankle coordination will have good mastery of ball playing techniques as well (Sandra $\&$ Bakhtiar, 2020). Furthermore, the description of the research results for agility is shown in table 6 below:

Table 6. Agility Result Statistics

\begin{tabular}{|c|c|c|c|c|c|c|c|c|c|}
\hline \multicolumn{10}{|c|}{ Descriptive Statistics } \\
\hline & $\mathrm{N}$ & Range & Minimum & Maximum & Sum & & ean & $\begin{array}{c}\text { Std. } \\
\text { Deviation }\end{array}$ & Variance \\
\hline & Statistic & Statistic & Statistic & Statistic & Statistic & Statistic & Std. Error & Statistic & Statistic \\
\hline Agility & 22 & 6.12 & 9.28 & 15.40 & 279.14 & 12.6882 & .37874 & 1.77645 & 3.156 \\
\hline Valid N (listwise) & 22 & & & & & & & & \\
\hline
\end{tabular}

Next is the agility variable which is the second independent variable in this study. Statistical analysis showed that for the agility variable, the mean $=12.6882$, range $=6.12$, sum $=279.14$, minimum $=9.28$, maximum $=15.40$, and standard deviation $=1.7765$. Therefore, the description of the results of the agility of the SSB TMM players in the City of Medan can be seen in table 7 below:

Table 7. Description of Agility Results

\begin{tabular}{cccc}
\hline Interval & Category & Frequency & Percentage $(\%)$ \\
\hline $\mathrm{X} \geq 8,75$ & Very High & 1 & 4.545 \\
$7,52 \leq \mathrm{X}<8,75$ & High & 11 & 50 \\
$6,29 \leq \mathrm{X}<7,52$ & Medium & 8 & 36.364 \\
$5,06 \leq \mathrm{X}<6,29$ & Low & 2 & 9.091 \\
$\mathrm{X} \leq 5,06$ & & Very Low & 0 \\
\hline & & & 22 \\
\hline
\end{tabular}


The agility component of soccer skills strongly influences soccer players (McMorris \& Graydon, 1997; Royal et al., 2006; Bullock et al., 2012). Furthermore, in the research of John Arwandi \& M Firdaus, it was emphasized that based on the results of hypothesis testing, it was concluded that there was an effect of variations in agility training on the ball dribbling ability of SSB Seroja Jambu Air Bukittinggi players (Arwandi \& Firdaus, 2021). The following research from Darmawan et al., (2020) concluded that increasing agility affects the ball dribbling skills of Futsal players at SMAN 4 Purwokerto which has a contribution of $31.6 \%$. Therefore, the description of the research results for ball dribbling ability can be seen in table 8 below:

Table 8. Statistics of Ball Dribbling Ability Descriptive Statistics

\begin{tabular}{lccccccccc}
\hline & \multicolumn{1}{c}{ Descriptive Statistics } & & & \multicolumn{2}{c}{ Std. } \\
& \multicolumn{1}{c}{ N } & Range & Minimum & Maximum & Sum & & Mean & Deviation & Variance \\
\cline { 2 - 11 } & Statistic & Statistic & Statistic & Statistic & Statistic & Statistic & Std. Error & Statistic & Statistic \\
\hline Dribbling Ability & 22 & 7.30 & 16.00 & 23.30 & 417.14 & 18.9609 & .42984 & 2.01614 & 4.065 \\
\hline Valid N (listwise) & 22 & & & & & & & & \\
\hline
\end{tabular}

Furthermore, the dependent variable is the ball dribbling ability of the SSB TMM players in the city of Medan in this study. Statistical analysis showed that the ball dribbling ability variable obtained the mean $=$ 18.9609 , range $=7.30$, sum $=417.14$, minimum $=16.00$, maximum $=23.30$, and standard deviation $=$ 2.0161. Therefore, the description of the results of the ball dribbling ability of SSB TMM players in the city of Medan can be seen in table 9 below:

Table 9. Description of the Results of the Ball Dribbling Ability

\begin{tabular}{|c|c|c|c|}
\hline Interval & Category & Frequency & Percentage (\%) \\
\hline $\mathrm{X} \geq 15,35$ & Very High & & \\
\hline $13,57 \leq X<15,35$ & High & 6 & 27.273 \\
\hline $11,79 \leq X<13,57$ & Medium & 12 & 54.545 \\
\hline $10,02 \leq \mathrm{X}<11,79$ & Low & 1 & 4.545 \\
\hline $\mathrm{X} \leq 10,02$ & Very Low & 3 & 13.636 \\
\hline \multicolumn{2}{|c|}{ Amount } & 22 & $100 \%$ \\
\hline
\end{tabular}

In this study, to see the normality test of the data, it can be seen in table 10 that from the 3 variables having a value of (sig.) $>0.05$, then the 3 variables are normally distributed and data analysis can be continued. The conclusion from Jofan Moningka's research is that there is a very close relationship between ankle coordination, agility, and speed on the ability to dribble in the fourth semester students of FIK UNIMA. The coefficient of determination of multiple analysis is $44.9 \%$ with the ability to dribble and $55.1 \%$ is influenced by other components that have not been studied such as field conditions, exercise intensity, balance, and others (Moningka et al., 2021).

Table 10. Normality Test

\begin{tabular}{llcl}
\hline Correlation & & Significance Level $(\boldsymbol{\rho})$ & Information \\
\hline $\mathrm{X}_{1}$ & with Y & 0,185 & Normal Distribution \\
$\mathrm{X}_{2}$ & with Y & 0,082 & Normal Distribution \\
\hline
\end{tabular}

Furthermore, linearity test is used to see the graph of the relationship that forms a straight line. So based on the linearity test, it can be seen in table 11, which it shows the strengthening of the value of (sig.) $>0.05$ so that the 3 variables $\mathrm{x} 1$, $\mathrm{x} 2$, have a linear relationship with $\mathrm{y}$, so that all requirements analysis are met and can be proceed. 
Table 11. Linearity Test

\begin{tabular}{cccc}
\hline Correlation & F Count & Significance $(\rho)$ & Information \\
\hline $\mathrm{X}_{1}$ with $\mathrm{P}$ & 2,927 & 0,064 & Linear \\
$\mathrm{X}_{2}$ with $\mathrm{Y}$ & 8,285 & 0,113 & Linear \\
\hline
\end{tabular}

In the first hypothesis test, namely ankle coordination. $\mathrm{H}_{0}$ : Ankle coordination has no significant relationship with dribbling ability. Ha: coordination has a significant relationship with dribbling ability, this can be seen in table 12 below.

Table 12. First Premise Barometer

\begin{tabular}{cccc}
\hline Correlation & rxy & significant & Information \\
\hline $\mathrm{x} 1$ to $\mathrm{y}$ & 0,53 & 0,05 & significant \\
\hline
\end{tabular}

From the probability table 12 , it can be seen that there is a correlation between coordination (x1) and ball dribbling ability (y) with a level of $0.046<0.05$ and an rxy gain of 0.53 , so $\mathrm{H}_{0}$ is rejected and $\mathrm{Ha}$ is accepted, so there is a relationship between ankle harmonization (x1) with ball dribbling ability (y). This can also be seen in the results of research investigating the inter-segmental coordination of the thigh calf from the kicking motion of the instep, where the dominant coordination pattern of the calf and the deep phase during the backward and forward swing respectively. Where good coordination results in high ball speed after the ball is kicked ( $\mathrm{Li}$ et al., 2016). In the second hypothesis test, namely agility. $\mathrm{H}_{0}$ : agility has a significant relationship with dribbling ability. $\mathrm{H}_{\mathrm{a}}$ agility has a significant relationship with dribbling ability, this can be seen in table 13 below.

Table 13. Second Premise Barometer

\begin{tabular}{cccc}
\hline Correlation & rxy & Significance & Information \\
\hline $\mathrm{x} 2$ to $\mathrm{y}$ & 0,63 & 0,037 & Significant \\
\hline
\end{tabular}

The probability obtained in table 13 can be seen the relationship between agility ( $\mathrm{x} 2$ ) and ability (y) at the level of $0.04<0.05$ and the acquisition of rxy 0.63, so $\mathrm{H}_{0}$ is rejected and $\mathrm{H}_{\mathrm{a}}$ is accepted until there is a significant relationship on agility (x2) with ball dribbling ability (y). In this study, it is not only multilateral coordination exercises and not only ladder agility training, but more about the importance of agility in technique in dribbling, where in the end good agility training improves dribbling skills (Padrón-Cabo et al., 2020). In the third multiple regression hypothesis test, $\mathrm{H}_{0}$ on both coordination and agility has no significant relationship with ball dribbling ability. Furthermore, $\mathrm{H}_{\mathrm{a}}$ on coordination and agility both have a significant relationship with ball dribbling ability. This can be seen in table 14 .

Table 14. Barometer of the Third Premise of Multiple Regression

\begin{tabular}{cccc}
\hline Fregression & Significance $(\boldsymbol{\rho})$ & Regression equation & Quantity \\
\hline 7,25 & 0,037 & $\mathrm{y}=14,880-0,232 \mathrm{x}_{1}+0,663 \mathrm{x}_{2}$ & $34,7 \%$ \\
\hline
\end{tabular}

The results obtained in table 14 can be seen the relationship of coordination and agility to the SSB TMM ball dribbling ability, the results of the study show a significant relationship between ankle coordination and agility with ball dribbling ability. This is reinforced by the research of David Armando \& Hari Amirullah Rahman that high ankle coordination is better and faster in mastering ball dribbling skills with a significance level of $0.000<0.05$ in soccer students aged 12-13 years (Armando \& Rahman, 2020). Coordination of eye and foot movements greatly affects dribbling ability (Zago et al., 2016; Armando \& Rahman, 2020).

Furthermore, in this study there are 3 (three) findings. One: this finding explains that the ball dribbling ability of SSB TMM players in the city of Medan can be improved by intensive ankle coordination exercises, the basis for making this conclusion is from the results of the Pearson correlation test with an rxy value of 0.531 at a significance level of $0.037<0.05$ so $\mathrm{H}_{0}$ is rejected and $\mathrm{H}_{\mathrm{a}}$ is accepted up to there is a significant relationship between ankle coordination and the ball dribbling ability of SSB TMM players in the city of Medan. In the coefficient of determination (R2) the analysis between ankle coordination and ball 
dribbling ability is $11.7 \%$. Two: this finding explains that the ball dribbling ability of SSB TMM players in the city of Medan can also be improved by intensive agility training, the basis for making this conclusion is from the results of the Pearson correlation test with an rxy value of 0.626 at a significance level of $0.037<$ 0.05 so $\mathrm{H}_{0}$ is rejected and $\mathrm{H}_{\mathrm{a}}$ is accepted until it is established. There is a significant relationship between agility and the ball dribbling ability of SSB TMM players in the city of Medan. In the coefficient of determination (R2) the analysis between agility and ball dribbling ability is $16.2 \%$. Three: the next finding explains that the ball dribbling ability of SSB TMM players in the city of Medan can be improved through ankle coordination exercises and intensive agility exercises, the basis for making this conclusion from the results of multiple regression tests with the acquisition of the ball dribbling ability of SSB TMM players in Medan city of 14,880 . Where the value of the correlation coefficient between ball dribbling ability with ankle coordination and agility is 0.626 . So the value of the coefficient of determination in the multiple regression analysis of ankle coordination and agility on the ball dribbling ability of SSB TMM players in the city of Medan is $34.7 \%$ and the influence of factors such as field conditions, intensity of exercise, speed, endurance, flexibility, balance, and others is $65.3 \%$.

Based on the conclusion of the research investigation, the independent variables consist of speed, agility, ankle coordination, balance, and motivation to the dependent variable, namely soccer playing skills. There is a positive influence between speed and ball playing skills, there is a positive influence between agility and ball playing skills, there is a positive influence between ankle coordination and ball playing skills, and there is a positive influence between balance and ball playing skills on students of the Faculty of Sports Science, State University of Makassar (Adil et al., 2018). Furthermore, based on research findings that soccer players must have skills that must be possessed such as shooting, controlling the ball, coordination, and other skills (Poulsen \& Ziviani, 2004; Nimphius et al., 2010; Ali, 2011; Ambegaonkar et al., 2013; Burhaein et al., 2020). Next, based on the conclusions of the research findings, it explains that there is a positive influence between ankle coordination, agility, speed, and dribbling ability in fourth semester students of FIK UNIMA. It can be concluded that ankle coordination exercises, intensive agility exercises that are carried out well greatly affect the ball dribbling ability in the soccer game of SSB TMM players in the City of Medan.

\section{CONCLUSION}

The findings of research data based on data analysis as well as the results of discussions that have been analyzed, the conclusions are as follows: (1) The premise barometer of the person on Ha is the acceptance of the relationship between coordination and ball dribbling ability which is significant for SSB TMM players with a coefficient of determination of $11.7 \%$. (2) Then the relationship between agility and ball dribbling ability is significant for SSB TMM players with a coefficient of determination of $16.2 \%$. (3) The next multiple regression barometer on the relationship between coordination and agility on the ball dribbling ability of SSB Tunas Muda Medan players obtained regression similarity in the coefficient of determination of $34.7 \%$, where the prerequisites by other factors have not been studied at $65.3 \%$ such as exercise intensity, condition field, speed, endurance, explosive power, and balance. So SSB TMM players who have good and good coordination and agility abilities will perform ball dribbling ability movements whose abilities are accurate and superior to opposing players. The results of this study can be concluded to improve dribbling skills, one form of exercise that must be done is coordination and agility training for SSB TMM players. In the future, it is expected that discoveries or research can be made that can improve dribbling skills with other training components for soccer players in soccer schools.

Meanwhile, the limitations of this study are that researchers have not investigated the intensity of exercise, speed, endurance, explosive power, balance, and field conditions which are some of the main factors in the movement of ball dribbling abilities in SSB TMM players in Medan city. Furthermore, this research was carried out during the outbreak of the covid 19 virus, this more or less affected the results of the research because the presence of players in training and during the test could not be done optimally. The absence of players also showed that players obeyed government regulations with the President's circular on Large-Scale Social Restrictions (PSBB) in the City of Medan. 


\section{REFERENCES}

Adil, A., Tangkudung, J., \& Hanif, A. S. (2018). The Influence of Speed, Agility, Coordination of Foot, Balance and Motivation on Skill of Playing Football. JIPES-Journal of Indonesian Physical Education and Sport, 4(1), 19-34. https://doi.org/10.21009/JIPES.041.02

Ali, A. (2011). Measuring soccer skill performance: a review. Scandinavian journal of medicine \& science in sports, 21(2), 170-183. https://doi.org/10.1111/j.1600-0838.2010.01256.x

Altavilla, G., Furino, F., Marika, D. P., \& Raiola, G. (2015). Physical skills, sport learning and socioaffective education. Sport Science, 8(Suppl. 1), 44-46.

Altug, Z., Altug, T., \& Altug, A. (1987). Research Application: A test selection guide for assessing and evaluating athletes. Strength \& Conditioning Journal, 9(3), 62-66. https://doi.org/10.1519/0744-0049

Ambegaonkar, J. P., Caswell, S. V, Winchester, J. B., Shimokochi, Y., Cortes, N., \& Caswell, A. M. (2013). Balance comparisons between female dancers and active nondancers. Research quarterly for exercise and sport, 84(1), 24-29. https://doi.org/10.1080/02701367.2013.762287

Andersen, T. E., Tenga, A., Engebretsen, L., \& Bahr, R. (2004). Video analysis of injuries and incidents in Norwegian professional football. British Journal of Sports Medicine, 38(5), 626-631. https://doi.org/10.1136/bjsm.2003.007955

Arikunto, S. (2013). Prosedur Penelitian Suatu Pendekatan Praktik. Yogyakarta: Rineka Cipta.

Armando, D., \& Rahman, H. A. (2020). The Effect of Training Methods and Eye-Foot Coordination on Dribbling Abilities in Students Aged 12-13 Years. Acta Facultatis Educationis Physicae Universitatis Comenianae, 60(1), 117-133.

Arwandi, J., \& Firdaus, M. (2021). Effect of Agility Training Towards Soccer Dribbling Skills. Advances in Health Sciences Research, 35(ICSSHT 2019), 7-10. https://doi.org/10.2991/ahsr.k.210130.002

Bullock, W., Panchuk, D., Broatch, J., Christian, R., \& Stepto, N. K. (2012). An integrative test of agility, speed and skill in soccer: Effects of exercise. Journal of Science and Medicine in Sport, 15(5), 431436. https://doi.org/10.1016/j.jsams.2012.03.002

Burhaein, E., Ibrahim, B. K., \& Pavlovic, R. (2020). The relationship of limb muscle power, balance, and coordination with instep shooting ability: A correlation study in under-18 football athletes. International Journal of Human Movement and Sports Sciences, 8(5), 265-270. https://doi.org/10.13189/saj.2020.080515

Candra, A. (2016). Pengaruh Latihan Menendang Menggunakan Imageri Terhadap Akurasi Tendangan ke Gawang. Journal Sport Area, 1(1), 1-10. https://doi.org/10.25299/sportarea.2016.vol1(1).371

Ceruso, R., Esposito, G., \& D'elia, F. (2019). Coordination attached to the qualitative aspects of football. Journal of Physical Education and Sport, 19(5), 1773-1776. https://doi.org/10.7752/jpes.2019.s5260

Dupri. (2016). Hubungan Explosive Power Otot Lengan dan Koordinasi Mata-Tangan Terhadap Kemampuan Servis Atas Atlet Bolavoli Kuansing Kabupaten Kuantan Singingi. Journal Sport Area, 1(2), 23-30. https://doi.org/https://doi.org/10.25299/sportarea 
D'elia, F. (2019). The training of physical education teacher in primary school. Journal of Human Sport and Exercise, 14(November), S100-S104. https://doi.org/10.14198/jhse.2019.14.Proc1.12

D’Isanto, T., D’Elia, F., Raiola, G., \& Altavilla, G. (2019). Assessment of sport performance: Theoretical aspects and practical indications. Sport Mont, 17(1), 79-82. https://doi.org/10.26773/smj.190214

Darmawan, F. D., Sulaiman, S., \& Setyawati, H. (2020). Contributions agility, resilience and self-confidence against ball dribbling skills (dribbling) futsal. Journal of Physical Education and Sports, 9(1), 14-19.

Deehan, D. J., Bell, K., \& McCaskie, A. W. (2007). Adolescent musculoskeletal injuries in a football academy. Journal of Bone and Joint Surgery - Series B, 89(1), 5-8. https://doi.org/10.1302/0301620X.89B1.18427

Egan, C. D., Verheul, M. H. G., \& Savelsbergh, G. J. P. (2007). Effects of Experience on the Coordination of Internally and Externally Timed Soccer Kicks. Journal of Motor Behavior, 39(5), 423-432. https://doi.org/10.3200/JMBR.39.5.423-432

Gamble, P. (2013). Strength and Conditioning for Team Sports: Sport-Specific Physical preparation for high performance, second edition. London: Taylor \& Francis.

Gazali, N. (2016). Pengaruh Metode Kooperatif dan Komando Terhadap Keterampilan Teknik Dasar Bermain Sepakbola. Journal Sport Area. 1(1), 56-62. https://doi.org/10.30814/sportarea.v1i1.373

Hardiyono, B., Nurkadri, N., Pratama, B. A., \& Laksana, A. A. N. P. (2019). The effect of the dominant muscle strength and self confidence on the results climb of the rock climbing's athlete. Jurnal SPORTIF: Jurnal Penelitian $\quad$ Pembelajaran. https://doi.org/10.29407/js_unpgri.v5i1.12857

Horicka, P., Simonek, J., \& Brodani, J. (2018). Diagnostics of reactive and running agility in young football players. Physical Activity Review, 6, 29-36. https://doi.org/10.16926/par.2018.06.05

Ilmi, M., \& Kiram, Y. (2019). Hubungan koordinasi mata-kaki dan kelincahan dengan dengan kemampuan dribbling pemain sepakbola di Sekolah Sepakbola (SSB) Excellent Kota Batusangkar. Patriot. 1(1), 204-212. https://doi.org/10.24036/patriot.v1i1.177

Jamalong, A. (2014). Peningkatan Prestasi Olahraga Nasional Secara Dini Melalui Pusat Pembinaan dan Latihan Pelajar (PPLP) dan Pusat Pembinaan dan Latihan Mahasiswa (PPLM). Jurnal Pendidikan Olahraga. 3(2), 156-168. http://dx.doi.org/10.31571/jpo.v3i2.127

Junge, A., Cheung, K., Edwards, T., \& Dvorak, J. (2004). Injuries in youth amateur soccer and rugby players - Comparison of incidence and characteristics. British Journal of Sports Medicine, 38(2), 168172. https://doi.org/10.1136/bjsm.2002.003020

Kharisma., \& Mubarok. (2020). Pengaruh latihan interval dengan latihan fartlek terhadap peningkatan vo2max pemain bola voli. Jurnal Ilmiah Fakultas Keguruan dan Ilmu Pendidikan, 6(02), 125-131. https://doi.org/10.35569/biormatika.v6i02.811

Kofotolis, N. D., Kellis, E., \& Vlachopoulos, S. P. (2007). Ankle sprain injuries and risk factors in amateur soccer players during a 2-year period. American Journal of Sports Medicine, 35(2), 458-466. https://doi.org/10.1177/0363546506294857 
Le Gall, F., Carling, C., Reilly, T., Vandewalle, H., Church, J., \& Rochcongar, P. (2006). Incidence of injuries in elite French youth soccer players: A 10-season study. American Journal of Sports Medicine, 34(6), 928-938. https://doi.org/10.1177/0363546505283271

Li, Y., Alexander, M., Glazebrook, C., \& Leiter, J. (2016). Quantifying Inter-Segmental Coordination during the Instep Soccer Kicks. International journal of exercise science, 9(5), 646-656.

McMorris, T., \& Graydon, J. (1997). The effect of exercise on cognitive performance in soccer-specific tests. Journal of Sports Sciences, 15(5), 459-468. https://doi.org/10.1080/026404197367092

Moningka, J., Pungus, M., Lomboan, E., Moningka, J., \& State, M. (2021). The relationship between eye foot coordination, agility and speed with ball dribbling skills in coaching education department. Indian Journal of Physical Education, Sports And Applied Science, 11(1), 5-9.

Nimphius, S., McGuigan, M. R., \& Newton, R. U. (2010). Relationship between strength, power, speed, and change of direction performance of female softball players. The Journal of Strength \& Conditioning Research, 24(4), 885-895. https://doi.org/10.1519/JSC.0b013e3181d4d41d

Nimphius, S. P. (2018). Change of Direction and Agility Tests: Challenging Our Current Measures of Performance. Strength and Conditioning Journal, 40(1), 26-38. https://doi.org/10.1519/SSC.0000000000000309

Oktarifaldi, Amra, F., \& Soniawan, V. (2020). The Effect of Agility, Foot-Eye Coordination, and Balance on Dribbling Ability: An Ex Post Facto Research at Balai Baru Football Academy Padang. Advances in Social Science, Education and Humanities Research, 464(Psshers 2019), 759-763. https://doi.org/10.2991/assehr.k.200824.169

Padrón-Cabo, A., Rey, E., Kalén, A., \& Costa, P. B. (2020). Effects of Training with an Agility Ladder on Sprint, Agility, and Dribbling Performance in Youth Soccer Players. Journal of Human Kinetics, 73(1), 219-228. https://doi.org/10.2478/hukin-2019-0146

Palmizal, Nurkadri, \& Pratama, B. A. (2019). Pengaruh latihan lompat gawang dan latihan lompat samping terhadap kemampuan heading bola pada permainan sepakbola ditinjau dari daya ledak otot tungkai. Jurnal Pendidikan Kepelatihan Olahraga, 11(2), 53-62. https://doi.org/10.26858/com.v11i2.13383

Perdima, F. E. (2017). Kontribusi kelincahan terhadap kemampuan dribbling bolabasket atlet SMA Negeri 1 Lebong Utara. Journal Sport Area, 2(1), 446. https://doi.org/10.25299/sportarea

Pfirrmann, D., Herbst, M., Ingelfinger, P., Simon, P., \& Tug, S. (2016). Analysis of injury incidences in male professional adult and elite youth soccer players: A systematic review. Journal of Athletic Training, 51(5), 410-424. https://doi.org/10.4085/1062-6050-51.6.03

Poulsen, A. A., \& Ziviani, J. M. (2004). Health enhancing physical activity: Factors influencing engagement patterns in children. Australian occupational therapy journal, 51(2), 69-79. https://doi.org/10.1046/j.1440-1630.2004.00420.x

Prakoso., \& Sugiyanto. (2017). The Effects of Endurance Training Methods and Limb Muscle on VO2Max Capacity Basketball Player. Jurnal Keolahragaan, 5(2), 151-160. https://doi.org/10.21831/jk.v5i2.10177 
Hawkins, R. D., \& Fuller, C. W. (1999). A prospective epidemiological study of injuries in four English professional football clubs. Br J Sports Med, 33, 196-203. http://dx.doi.org/10.1136/bjsm.33.3.196

Royal, K. A., Farrow, D., Mujika, I., Halson, S. L., Pyne, D., \& Abernethy, B. (2006). The effects of fatigue on decision making and shooting skill performance in water polo players. Journal of Sports Sciences, 24(8), 807-815. https://doi.org/10.1080/02640410500188928

Sakti, B. P. I. (2017). Hubungan koordinasi mata-kaki dan kelincahan dengan keterampilan menggiring bola dalam permainan sepakbola pada siswa ekstrakurikuler SMA Negeri 2 Lubuklinggau. Biormatika: Jurnal Ilmiah Fakultas Keguruan dan Ilmu Pendidikan, 3(2), 140-146.

Sandra, A. N., \& Bakhtiar, S. (2020). The Effect of Playing Activities, Eye Coordination and Confidence on Football Players at SSB UIR Pekanbaru. 1st Progress in Social Science, Humanities and Education Research Symposium (PSSHERS 2019), 792-796.

Saputra, A., Muzaffar, A., Alpaizin, M., \& Wibowo, Y. G. (2019). Analisis Kemampuan Teknik Dasar Pemain Sepak Bola Ssb Pratama Kabupaten Batanghari. Indonesian Journal of Sport Science and Coaching, 1(1), 1-10. https://doi.org/10.22437/ijssc.v1i1.6311

Šimonek, J., Horička, P., \& Hianik, J. (2016). Differences in pre-planned agility and reactive agility performance in sport games. Acta Gymnica, 46(2), 68-73. https://doi.org/10.5507/ag.2016.006

Spiteri, T., Cochrane, J. L., Hart, N. H., Haff, G. G., \& Nimphius, S. (2013). Effect of strength on plant foot kinetics and kinematics during a change of direction task. European Journal of Sport Science, 13(6), 646-652. https://doi.org/10.1080/17461391.2013.774053

Stølen, T., Chamari, K., Castagna, C., \& Wisløff, U. (2005). Physiology of Soccer. Sports Medicine, 35(6), 501-536. https://doi.org/10.2165/00007256-200535060-00004

Sugiono. (2016). Metode Penelitan Kuantitatif, Kualitatif dan R\&D. Bandung: Alfabeta.

Supardi, U. S. (2013). Aplikasi Statistika Dalam Penelitian Edisi Revisi. Jakarta: Smart.

Supriadi, A. (2015). Hubungan koordinasi mata-kaki terhadap keterampilan menggiring bola pada permainan sepakbola. Jurnal Ilmu Keolahragaan, 14(1), 1-14. https://doi.org/10.24114/jik.v14i1.6097

Susilawati, D. (2018). Tes dan Pengukuran. Bandung: UPI Sumedang Press.

Tessitore, A., Perroni, F., Cortis, C., Romainmeeusen, R., Lupo, C., \& Capranica, L. (2011). Coordination of soccer players during preseason training. Journal of Strength and Conditioning Research. 25(11), 3059-3069. https://doi.org/10.1519/JSC.0b013e318212e3e3

Udam, M. (2017). Pengaruh Latihan Shuttle-Run dan Zig-zag terhadap Kemampuan Dribbling Bola pada Siswa Sekolah Sepakbola (SSB) Imanuel USia 13-15 di Kabupaten Jayapura. Jurnal Pendidikan Jasmani Olahraga dan Kesehatan, 3(1), 58-71. https://doi.org/10.31957/jop.v3i1.1230

Woods, C., Hawkins, R. D., Maltby, S., Hulse, M., Thomas, A., \& Hodson, A. (2001). The association football medical research programme: an audit of injuries in professional football. Br J Sports Med, 35, 43-47. http://dx.doi.org/10.1136/bjsm.35.1.43 
Yen, S. C., Chui, K. K., Corkery, M. B., Allen, E. A., \& Cloonan, C. M. (2017). Hip-ankle coordination during gait in individuals with chronic ankle instability. Gait and Posture. 53, 193-200. https://doi.org/10.1016/j.gaitpost.2017.02.001

Young, W. B., James, R., \& Montgomery, I. (2002). Is muscle power related to running speed with changes of direction? Journal of Sports Medicine and Physical Fitness, 42(3), 282-288.

Zago, M., Piovan, A. G., Annoni, I., Ciprandi, D., Iaia, F. M., \& Sforza, C. (2016). Dribbling determinants in sub-elite youth soccer players. Journal of Sports Sciences, 34(5), 411-419. https://doi.org/10.1080/02640414.2015.1057210

Zemková, E., \& Hamar, D. (2009). The effect of soccer match induced fatigue on neuromuscular performance. Kinesiology, 41(2), 195-202. 